\title{
Relation Between Chlorophyll-A Concentration and Red Tide in the Intensive Study Area of the Ariake Sea, Japan in Winter Seasons by using MODIS Data
}

\author{
Kohei Arai 1 \\ 1Graduate School of Science and Engineering \\ Saga University \\ Saga City, Japan
}

\begin{abstract}
Relation between chlorophyll-a concentration and red tide in the intensive study area of the back of Ariake Sea, Japan in the recent winter seasons is investigated by using MODIS data. Mechanism of red tide appearance is not so clarified. On the other hand, chlorophyll-a concentration can be estimated with satellite remote sensing data. An attempt is made for estimation of the location and size of red tide appearance. In particular, severe damage due to red tide is suspected in the winter seasons now a day. Therefore, 6 years (winter 2010 to winter 2015) data of MODIS data derived chlorophyll-a concentration and truth data of red tide appearance (the location and the volume) which are provided by Saga Prefectural Fishery Promotion Center: SPFPC (once/10 days of shipment data) have been investigated. As the results of the investigation, it is found that a strong correlation between the chlorophyll-a concentration and red tide appearance together with the possible sources of the red tide.
\end{abstract}

Keywords—chlorophyl-a concentration; red tide; diatom; MODIS; satellite remote sensing

\section{INTRODUCTION}

The Ariake Sea is the largest productive area of Nori (Porphyra yezoensis 1) in Japan. In winters of 2012, 2013, 2014 and 2015, a massive diatom bloom occurred in the Ariake Sea, Japan [1]. In case of above red tides, bloom causative was Eucampia zodiacus 2 . This bloom has being occurred several coastal areas in Japan and is well reported by Nishikawa et al. for Harimanada sea areas [2]-[10]. Diatom blooms have recurrently occurred from late autumn to early spring in the coastal waters of western Japan, such as the Ariake Sea [11] and the Seto Inland Sea [12], where large scale "Nori" aquaculture occurs. Diatom blooms have caused the exhaustion of nutrients in the water column during the "Nori" harvest season. The resultant lack of nutrients has suppressed the growth of "Nori" and lowered the quality of "Nori" products due to bleaching with the damage of the order of billions of yen [3].

This bloom had been firstly developed at the eastern part of the Ariake Sea. However, as the field observation is time-

\footnotetext{
${ }_{2}^{1}$ http://en.wikipedia.org/wiki/Porphyra

http://www.eos.ubc.ca/research/phytoplankton/diatoms/centric/eucampia/e_zo diacus.html
}

consuming, information on the developing process of the red tide, and horizontal distribution of the red tide has not yet been clarified in detail. To clarify the horizontal distribution of red tide, and its temporal change, remote sensing satellite data is quite useful.

In particular in winter, almost every year, relatively large size of diatoms of Eucampia zodiacus appears in Ariake Sea areas. That is one of the causes for damage of Porphyra yezoensis. There is, therefore, a strong demand to prevent the damage from Nori farmers. Since 2007, Asteroplanus karianus appears in the Ariake Sea almost every year. In addition, Eucampia zodiacus appears in Ariake Sea since 2012.

The chlorophyll-a concentration algorithm developed for MODIS $^{3}$ has been validated [13]. The algorithm is applied to MODIS data for a trend analysis of chlorophyll-a distribution in the Ariake Sea area in winter during from 2010 to 2015 is made [14]. On the other hand, red tide appearance (location, red tide species, the number of cells in unit water volume by using microscopy) are measured from the research vessel of the Saga Prefectural Fishery Promotion Center: SPFPC by once/10 days basis. The location and size of the red tide appearance together with the red tide source would be clarified by using SPFPC data. Match-up data of MODIS derived chlorophyll-a concentrations are used for investigation of relations between MODIS data and truth data of the red tide appearance.

In the next section, the method and procedure of the experimental study is described followed by experimental data and estimated results. Then conclusion is described with some discussions.

\section{METHOD AND PROCEDURE}

\section{A. The Procedure}

The purposes of the research is as follows,

1) At first, MODIS derived chlorophyll-a concentration has to be validated with the truth data (shipment data of the number of cells/ml of red tide species provided by SPFPC),

2) Possible sources of the red tide species has to be estimated,

${ }^{3}$ http://modis.gsfc.nasa.gov/ 
3) Spatial relation among several districted sea areas has to be clarified (more precisely, red tide relations between Ariake bay and Isahaya bay as well as Kumamoto offshore have to be clarified),

4) Mechanism of red tide in the intensive study sea areas will be clarified after all.

Therefore, the following procedure of the experimental study is proposed,

1) Gather MODIS data of the Ariake Sea areas together with the chlorophyll-a concentration estimation with the MODIS data,

2) Gather the truth data of red tide appearance (the location and the size of the red tide) together with the red tide species and the number of cells in unit water volume,

3) Investigation on relation between the truth data and the match-up of MODIS data.

\section{B. The Intensive Study Areas}

Fig. 1 shows the intensive study areas in the Ariake Sea area, Kyushu, Japan.

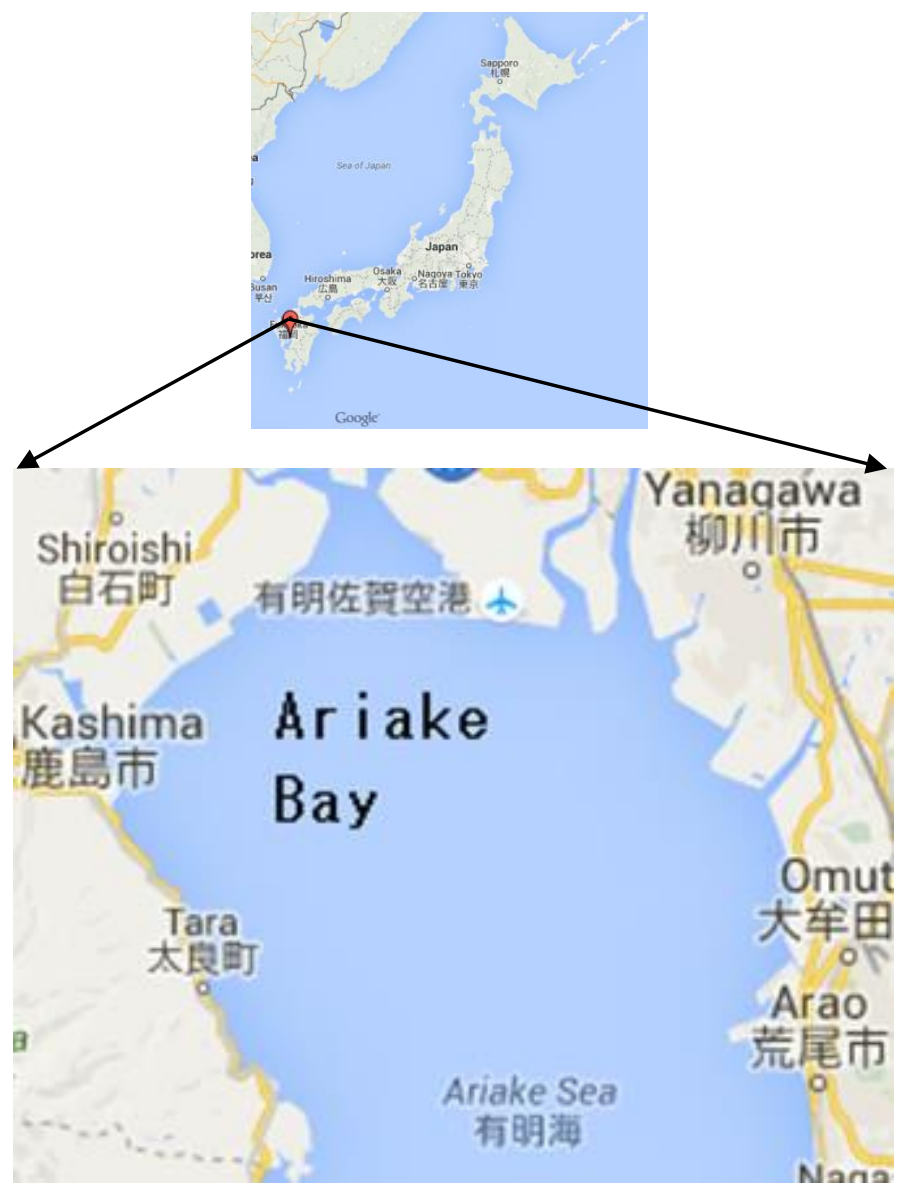

Fig. 1. Intensive study areas

\section{EXPERIMENTS}

\section{A. The Data Used (MODIS Data Derived Chlorophyll-a Concentration and Truth Data)}

MODIS derived chlorophyll-a concentration which area acquired for the observation period of one month (in January) in 2010 to 2015 is used for the experiments. MODIS data are acquired on these days. MODIS data cannot be acquired on the rest of days due to cloudy condition. White portions in the chlorophyll-a concentration images are cloud covered areas.

These data are acquired on January 4, 6, 7, 8, 9, $9^{4}, 10,12$, 17, 18, 20, 23, February 1, 3, 6, 9, 13, 14, 20, 27, and March 2 in 2015, respectively. Meanwhile, MODIS data are acquired on January 10, 13, 15, 16, 19, 23, 24, 26, 27, 29, 30 and February 4 in 2014, respectively. In 2013, MODIS data are acquired on January 4, 6, 10, 12, 15, 18, 19, 25, 28, 30, and 31, respectively while, in 2012. MODIS data are acquired on January 2, 6, 7, 12, 17, 20, 21, 23, 26, 29, 30, and 31, respectively. Furthermore, in 2011, MODIS data are acquired on January $1,2,7,8,14,17,22,26$, and 27 , respectively while, in 2010, MODIS data are acquired on January 1, 3, 4, 9, 14, 16, $17,18,22,24,26,27$, and 29 , respectively. All the data are shown in the previous paper which deals with "Locality of Chlorophyll-a Distribution in the Intensive Study Area of the Ariake Sea, Japan in Winter Seasons Based on Remote Sensing Satellite Data".

It is found the following red tide at around the Shiota river mouth on January 212010 ,

\section{Asterionella kariana; $3280 \mathrm{cell} s / \mathrm{ml}$}

\section{Skeletonema costatum: $1330 \mathrm{cells} / \mathrm{ml}$}

Fig. 2 shows the superimposed image with MODIS data derived chlorophyll-a concentration and truth data which is provided by Saga Prefectural Fishery Promotion Center. The number in the figure denotes the number of red tide cells / $\mathrm{ml}$.

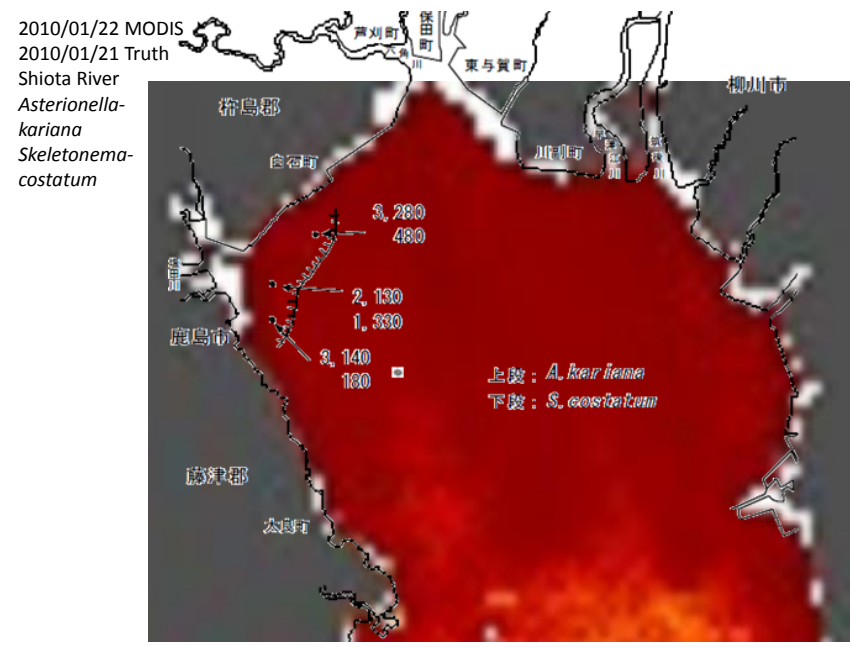

Fig. 2. Superimposed image with MODIS data derived chlorophyll-a concentration and truth data which is provided by Saga Prefectural Fishery Promotion Center

\footnotetext{
${ }^{4}$ There are two satellites which carry MODIS instruments, Terra and AQUA. Two MODIS data derived chlorophyll-a concentrations can be acquired occasionally.
} 
As shown in the figure, the possible source of red tide would be nutrition rich water flown from the Shiota river mouth. MODIS derived chlorophyll-a concentration is distributed in the whole Ariake bay area while truth data shows red tide is distributed around the Shiota river mouth and Shiroishi offshore.

On January11 2011, it is found the following red tide along with the Shiroishi town offshore to the Shiota river mouth,

\section{Asterionella kariana; $10150 \mathrm{cells} / \mathrm{ml}$}

Fig.3 shows the superimposed image with MODIS data derived chlorophyll-a concentration and truth data which is provided by Saga Prefectural Fishery Promotion Center. The number in the figure denotes the number of red tide cells / $\mathrm{ml}$.

Although the truth data say that the red tide is distributed at around Shiota river mouth and Shiroishi offshore, it cannot be seen due to the fact that it is covered with cloud in the MODIS data derived chlorophyll-a concentration.

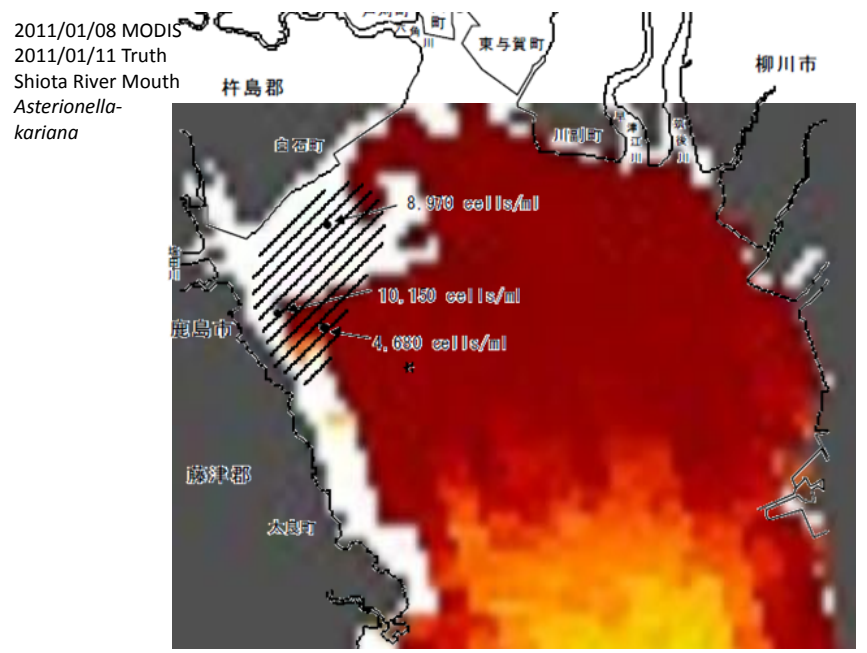

Fig. 3. Superimposed image with MODIS data derived chlorophyll-a concentration and truth data which is provided by Saga Prefectural Fishery Promotion Center

It is found the following red tide at around the Kashima offshore on February 25 2011,

\section{Asterionella kariana; 4950 cells $/ \mathrm{ml}$}

Fig.4 shows the truth data of red tide distribution which appeared at around Kashima offshore. Unfortunately, MODIS data cannot be acquired on that day.

It is found the following red tide at around the Shiota River Mouth on December 30 2011,

\section{Asterionella kariana; 5150 cells $/ \mathrm{ml}$}

Fig.5 shows the superimposed image with MODIS data derived chlorophyll-a concentration and truth data which is provided by Saga Prefectural Fishery Promotion Center.

The red tide is distributed Shiota river mouth and Kashima offshore.

On January 23 2012, it is found the following red tide at the Shiroishi offshore,

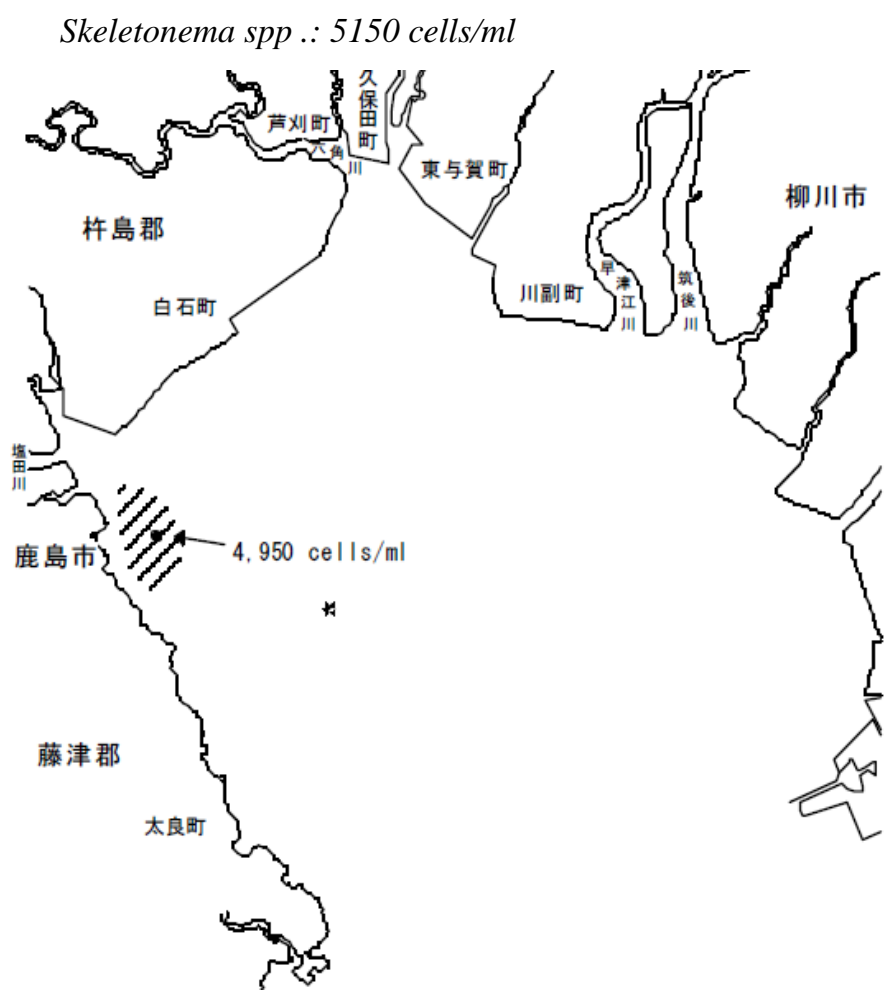

Fig. 4. Truth data of red tide distribution which appeared at around Kashima offshore

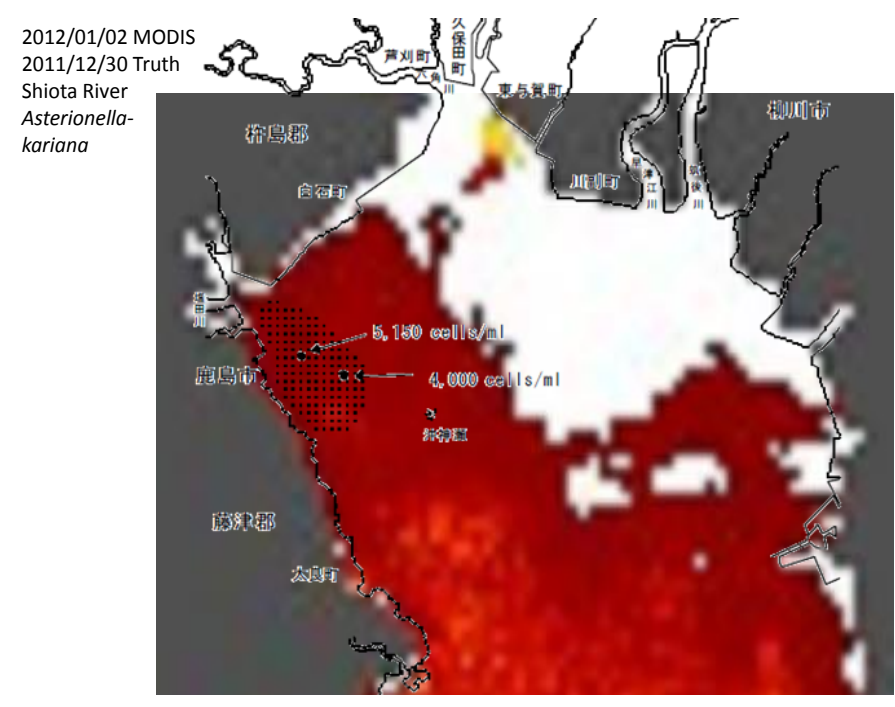

Fig. 5. Superimposed image with MODIS data derived chlorophyll-a concentration and truth data which is provided by Saga Prefectural Fishery Promotion Center

Fig.6 shows the superimposed image with MODIS data derived chlorophyll-a concentration and truth data which is provided by Saga Prefectural Fishery Promotion Center. The red tide is distributed at around Shiota river mouth and Shiroishi offshore.

The following red tide is found widely along with the Kawazoe offshore to the Tara offshore on February 22 2012,

Eucampia zodiacus: 1,090 cells $/ \mathrm{ml}$ 
Fig.7 shows the truth data of red tide distribution which appeared at around Kawazoe offshore. Unfortunately, MODIS data cannot be acquired on that day.

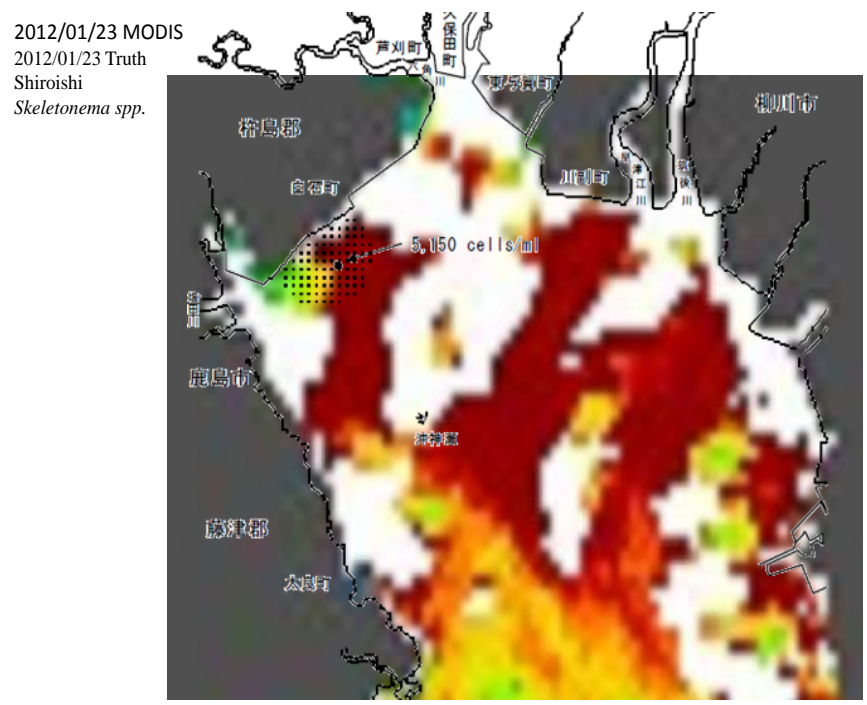

Fig. 6. Superimposed image with MODIS data derived chlorophyll-a concentration and truth data which is provided by Saga Prefectural Fishery Promotion Center

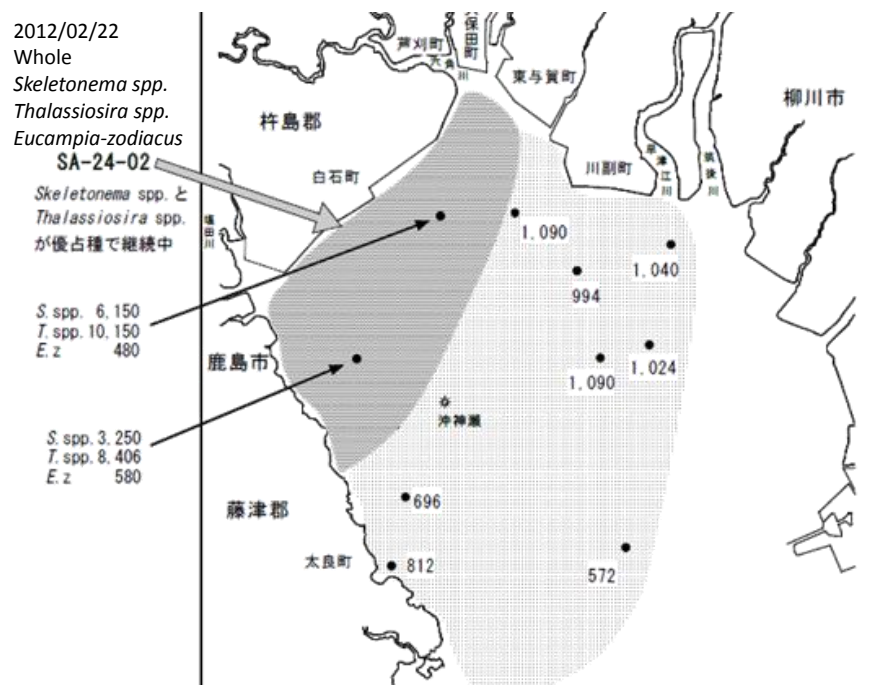

Fig. 7. Truth data of red tide distribution which appeared at around Kawazoe offshore

Also it is found the following red tide along with the Shiota river mouth to the Kashima offshore on December 31 2012 ,

\section{Skeletonema spp .: $6110 \mathrm{cells} / \mathrm{ml}$}

Fig.8 shows the truth data of red tide distribution which appeared at around Kashima offshore and MODIS data derived chlorophyll-a concentration which is acquired on January 42013.

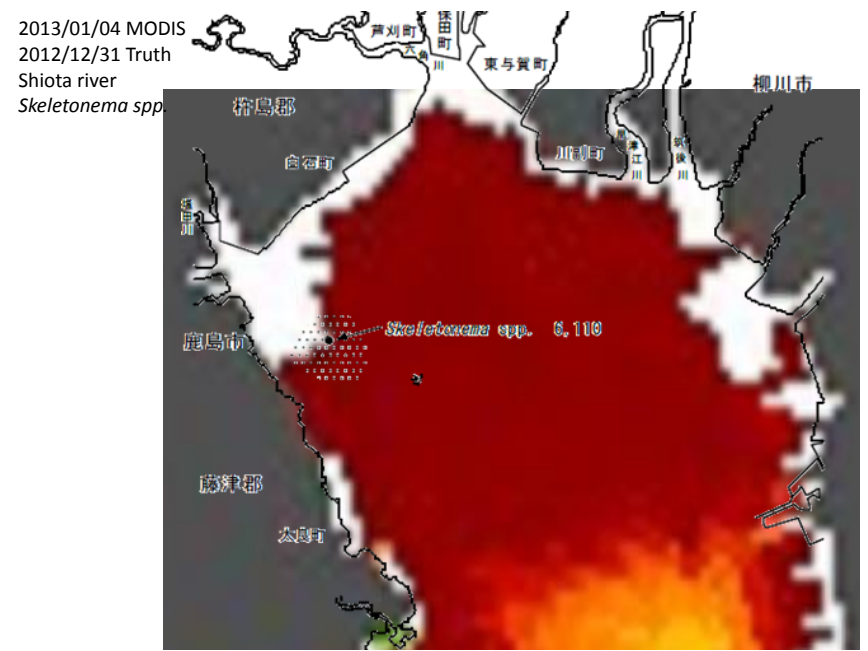

Fig. 8. Truth data of red tide distribution which appeared at around Kawazoe offshore and MODIS data derived chlorophyll-a concentration which is acquired on January 42013

On January 7 2013, the following red tide are observed along with the Shiota river mouth to the Shiroishi offshore,

\section{Asterionella kariana; 5630 cells $/ \mathrm{ml}$}

\section{Skeletonema costatum: $3390 \mathrm{cells} / \mathrm{ml}$}

Fig.9 shows superimposed image of the truth data and the MODIS data derived chlorophyll-a concentration. The red tide distribution derived from MODIS data is almost coincident to the truth data.

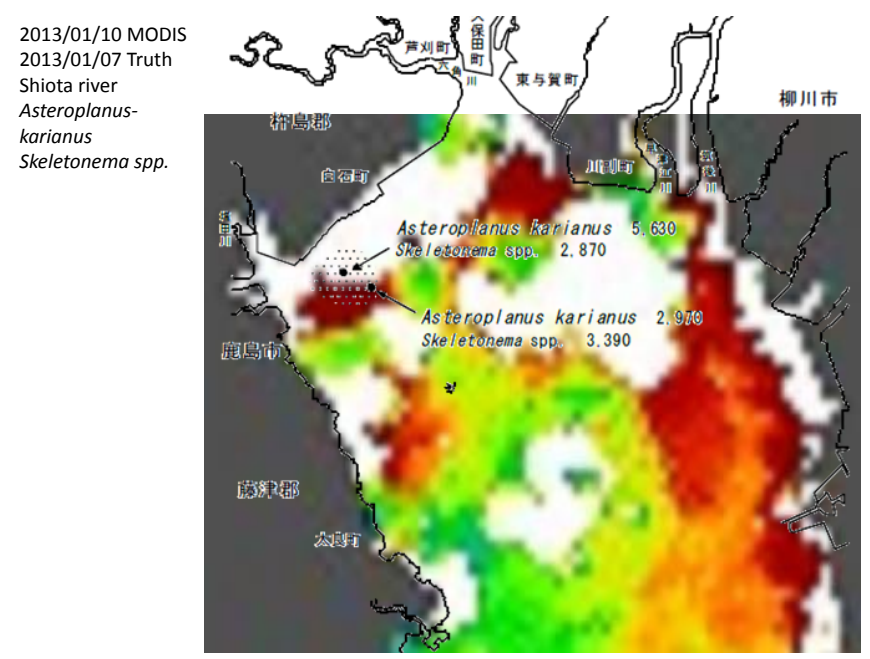

Fig. 9. Superimposed image of the truth data and the MODIS data derived chlorophyll-a concentration

It is found the following red tide at a small area of the Kashima offshore on February 18 2013,

Eutreptia pertyi and Eutreptiella spp.: $116600 \mathrm{cells} / \mathrm{ml}$

Asterionella kariana; $7340 \mathrm{cells} / \mathrm{ml}$ 
Fig.10 shows the truth data of red tide distribution which appeared at around Kashima offshore. Unfortunately, MODIS data cannot be acquired on that day.

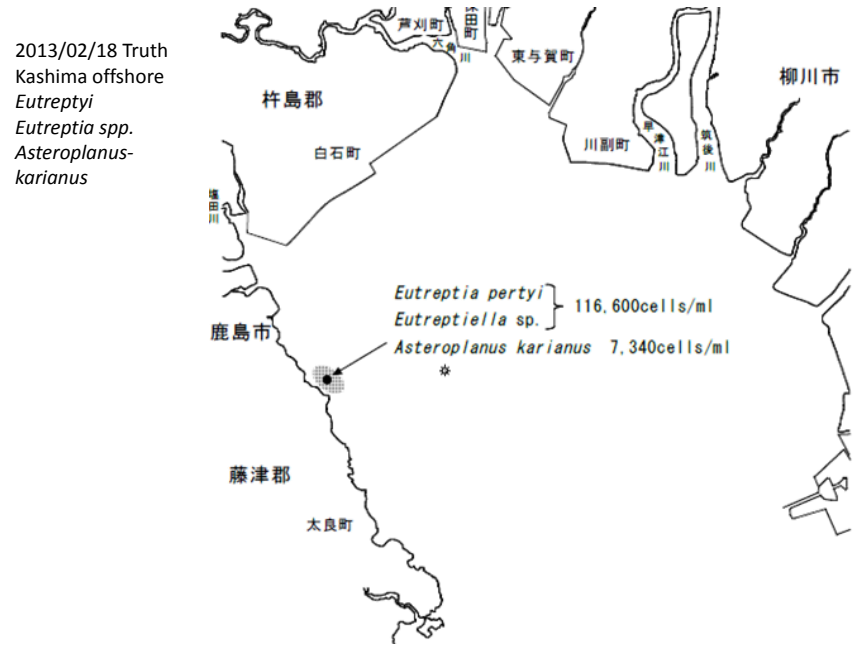

Fig. 10. Truth data of red tide distribution which appeared at around Kashima offshore

On February 26 2013, the following red tide is found almost entire Ariake Bay areas except Rokkaku river mouth,

\section{Eucampia zodiacus: 980 cells $/ \mathrm{ml}$}

\section{Rhizosolenia setigera: 58 cells $/ \mathrm{ml}$}

Fig.11 shows the truth data of red tide distribution. Unfortunately, MODIS data cannot be acquired on that day.

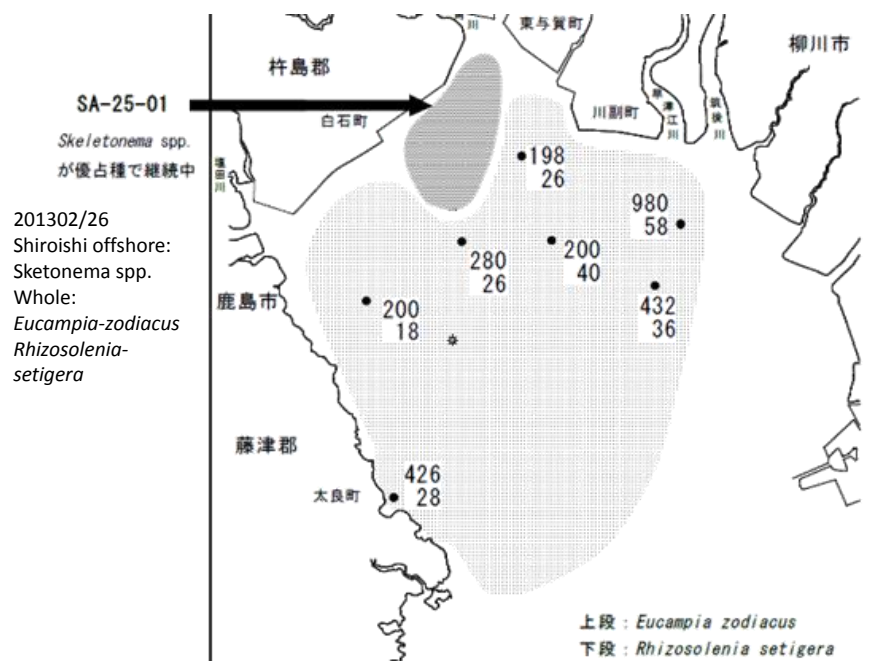

Fig. 11. Truth data of red tide distribution (almost all over the Ariake Bay area)

It is found the following red tide at the Shiraishi offshore on January 62014 ,

\section{Asterionella kariana; 4830 cells $/ \mathrm{ml}$}

Fig.12 shows the superimposed image of the truth data of red tide and the MODIS data derived chlorophyll-a concentration which is acquired on January 102014.

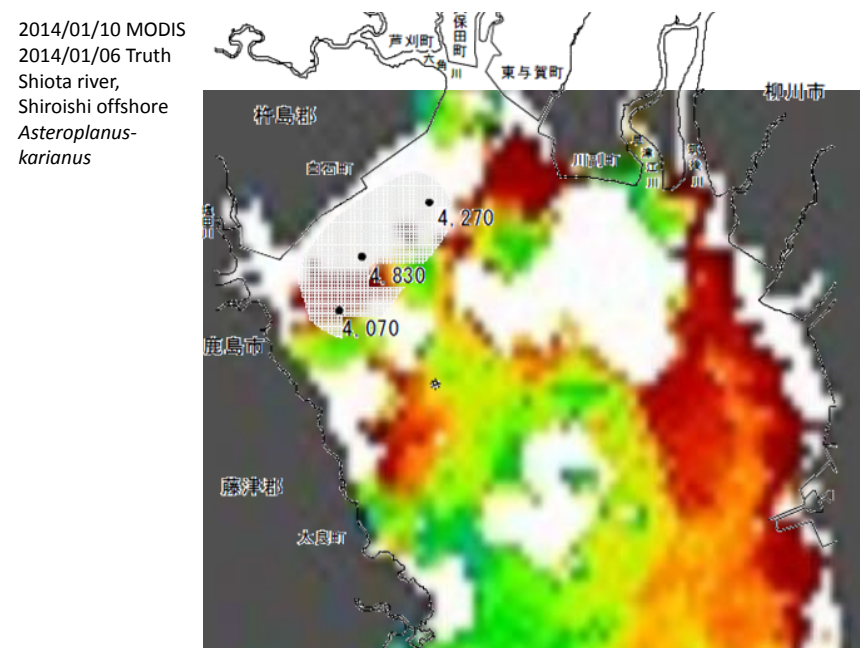

Fig. 12. Superimposed image of the truth data of red tide and the MODIS data derived chlorophyll-a concentration which is acquired on January 102014

The following red tide is observed at the Shiroishi offshore on January 162014 ,

\section{Skeletonema spp .: 6110 cells $/ \mathrm{ml}$}

Thalassiosira spp.: $1510 \mathrm{cells} / \mathrm{ml}$

Fig.13 shows the superimposed image of the truth data of red tide and the MODIS data derived chlorophyll-a concentration which is acquired on January 16 2014. It seems that the red tide which is originated from Rokkaku river mouth and Shiota river mouth propagated to Shiroishi offshore along with the sea water current.

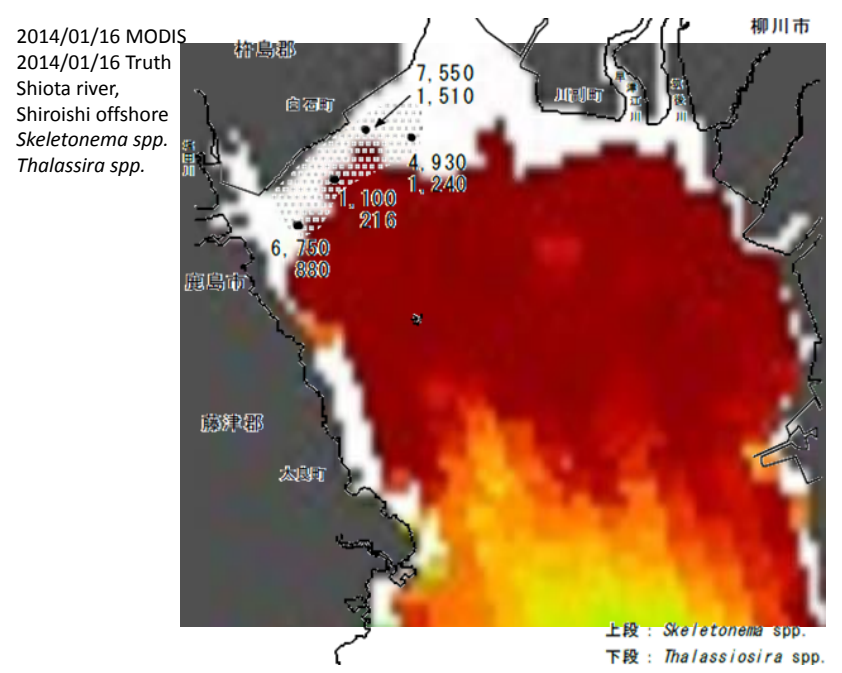

Fig. 13. Superimposed image of the truth data of red tide and the MODIS data derived chlorophyll-a concentration which is acquired on January 162014

On February 6 2014, the following red tide is observed almost whole Ariake bay area except the Shiraishi offshore,

\section{Eucampia zodiacus: 568 cells/ml}

Fig.14 shows the superimposed image of the truth data of red tide and the MODIS data derived chlorophyll-a concentration which is acquired on February 42014. 


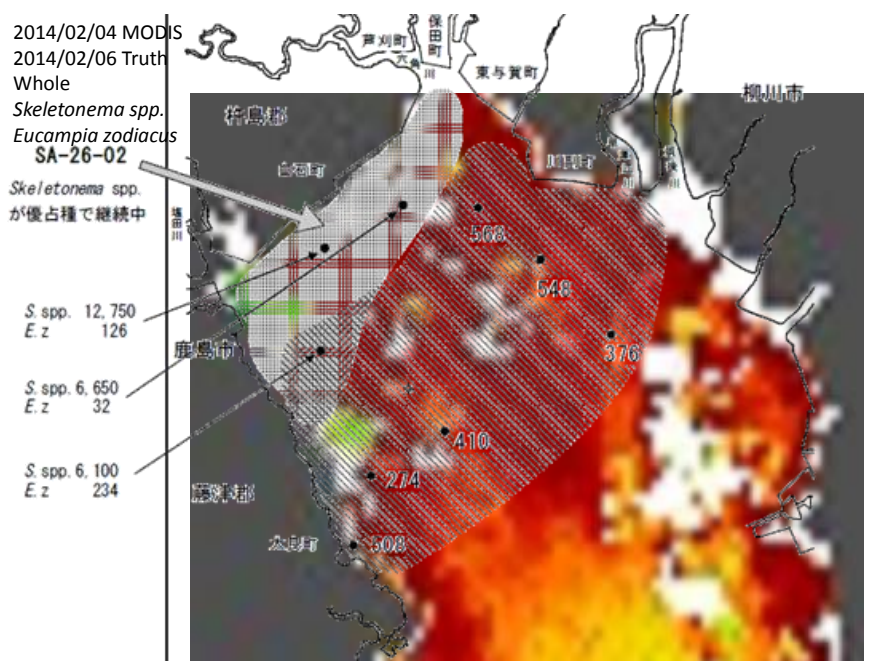

Fig. 14. Superimposed image of the truth data of red tide and the MODIS data derived chlorophyll-a concentration which is acquired on February 42014

It is observed the following red tide along with the Shiroishi offshore to the Tara offshore on December 302014 ,

\section{Asterionella kariana; 3890 cells/ml}

\section{Skeletonema costatum: 8750 cells $/ \mathrm{ml}$}

On the other hand, MODIS data is acquired on January 4 2015, clouds are observed almost everywhere in the Ariake bay area though. Fig. 15 shows the super imposed image of the truth data of red tide and the MODIS data derived chlorophylla concentration which is acquired on January 4 2015. It seems that the red tide which is originated from the Shiota river mouth propagated to the Kashima and Tara offshore and a far beyond along with the sea water current.

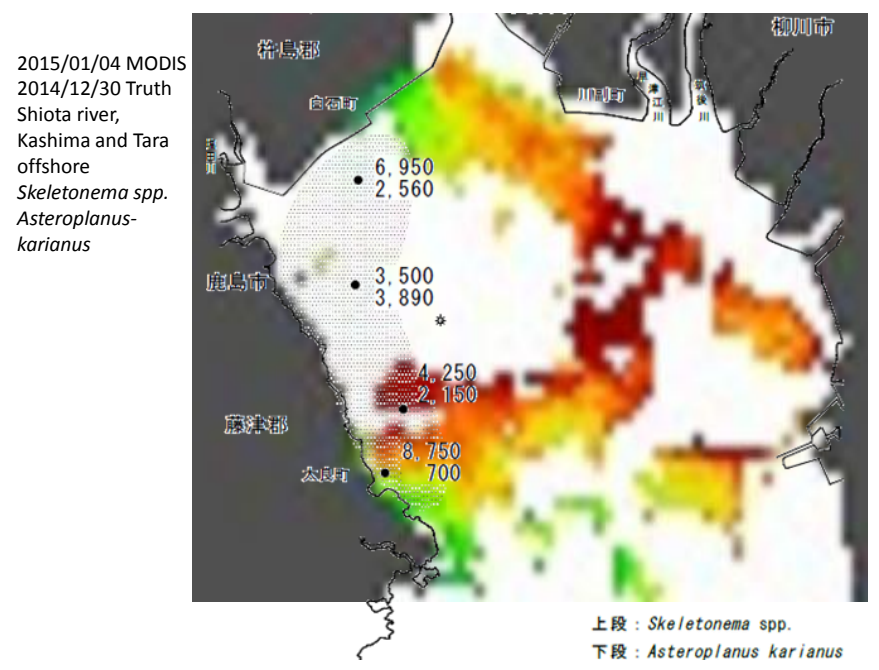

Fig. 15. Superimposed image of the truth data of red tide and the MODIS data derived chlorophyll-a concentration which is acquired on January 42015

On March 6 2015, the following red tide is observed along with the Kashima offshore to the Tara offshore,
Fig.16 shows the superimposed image of truth data and the MODIS data derived chlorophyll-a concentration which is acquired on March 52015.

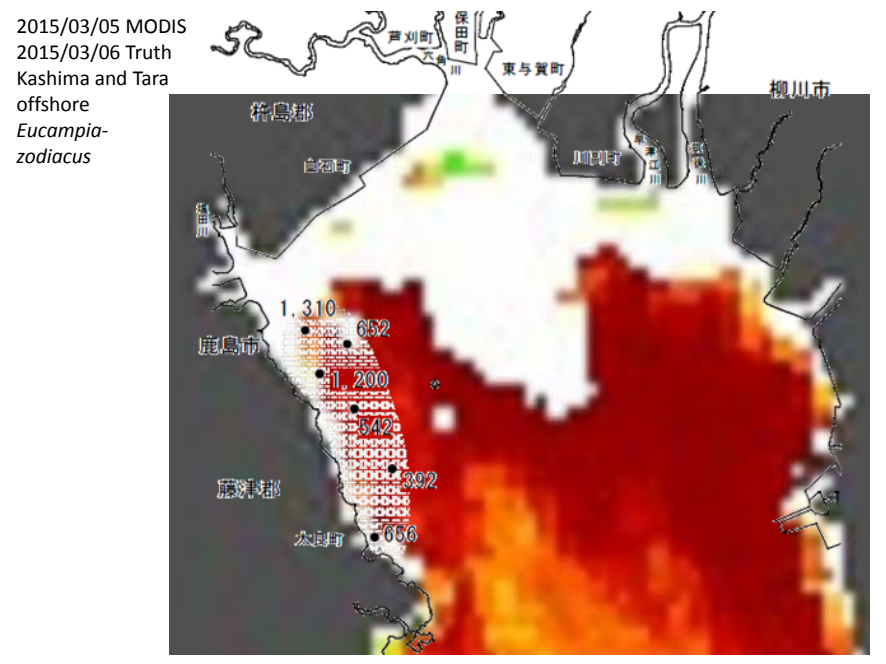

Fig. 16. Superimposed image of truth data and the MODIS data derived chlorophyll-a concentration which is acquired on March 52015

\section{B. Trend Analysis in the Case of March 2015}

MODIS observed the same sea areas more frequently in this period. Fig. 17 shows the superimposed images of the truth data and the MODIS data derived chlorophyll-a concentration which are acquired in the period starting from February 27 to March 5 2015. Chlorophyll-a is distributed densely in the Ariake bay area and Isahaya bay area on February 27. Then the densely distributed chlorophyll-a is flown to the south direction along with the sea water current in the Ariake bay while the densely distributed chlorophyll-a is flown from the Isahaya bay to the Taira-machi and far beyond the Shimabara offshore. Therefore, it may say that the sources of red tide are different between Ariake bay and Isahaya bay.

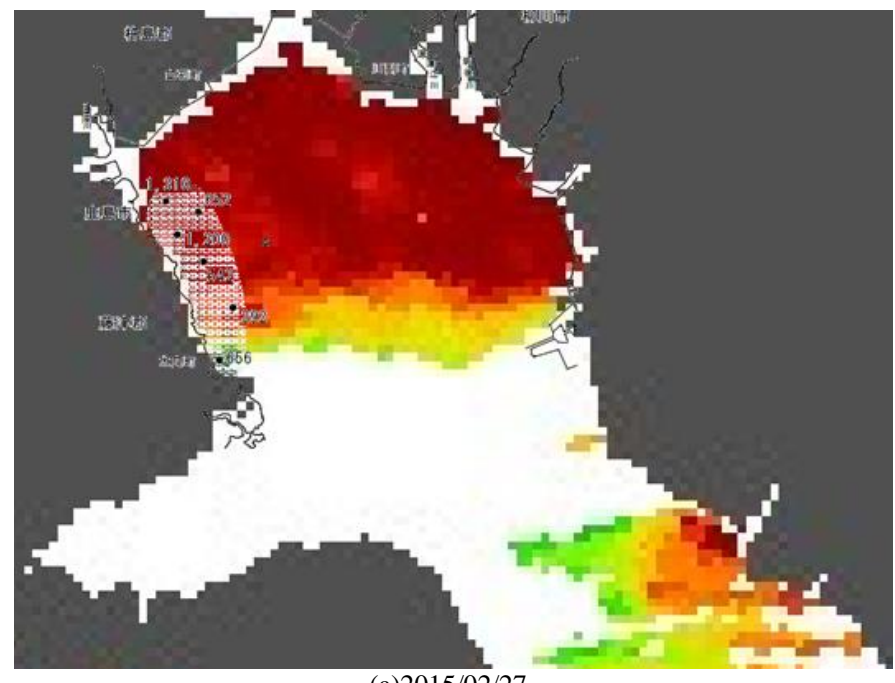

Eucampia zodiacus: 1310 cells/ml 


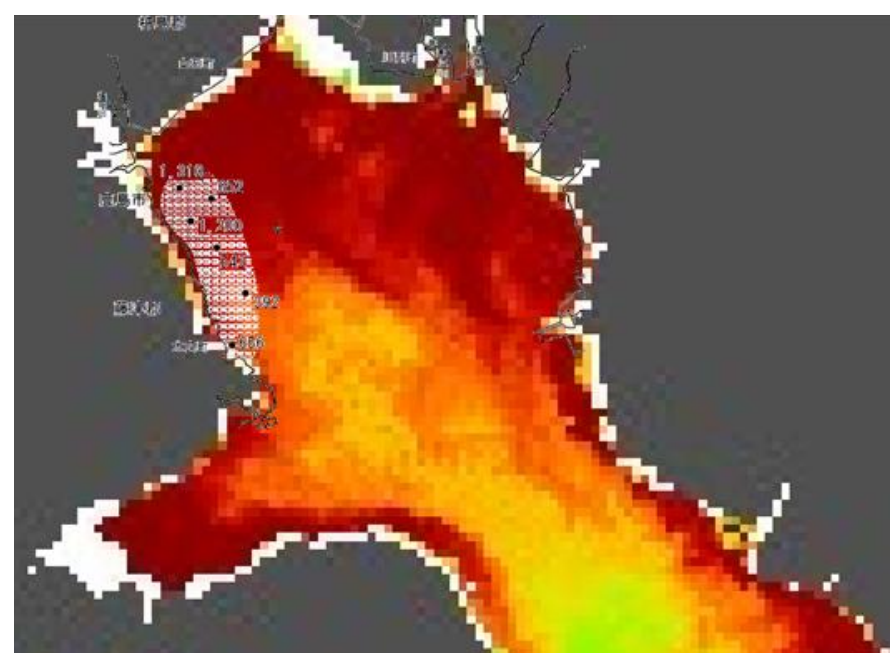

(b) $2015 / 03 / 02$

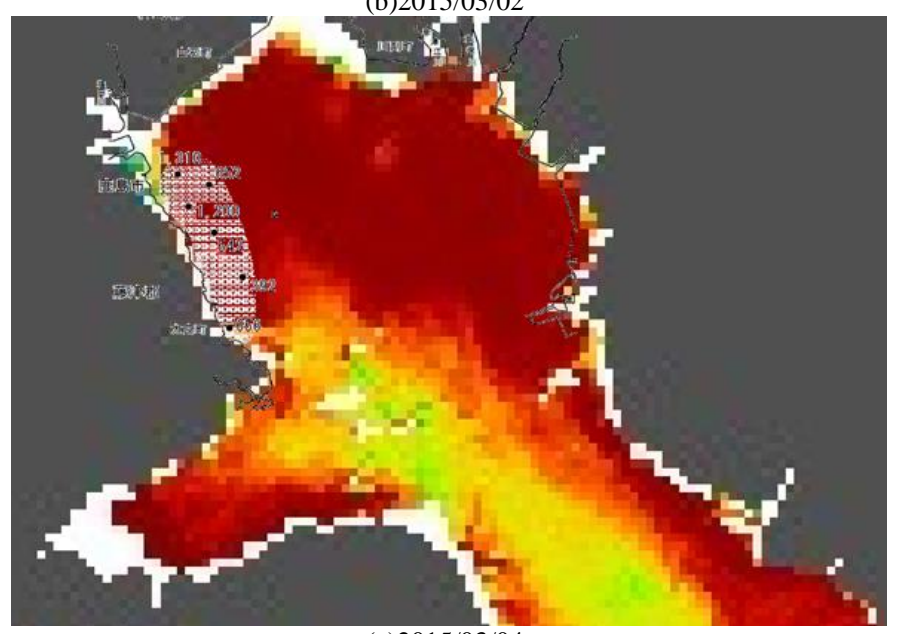

(c) $2015 / 03 / 04$

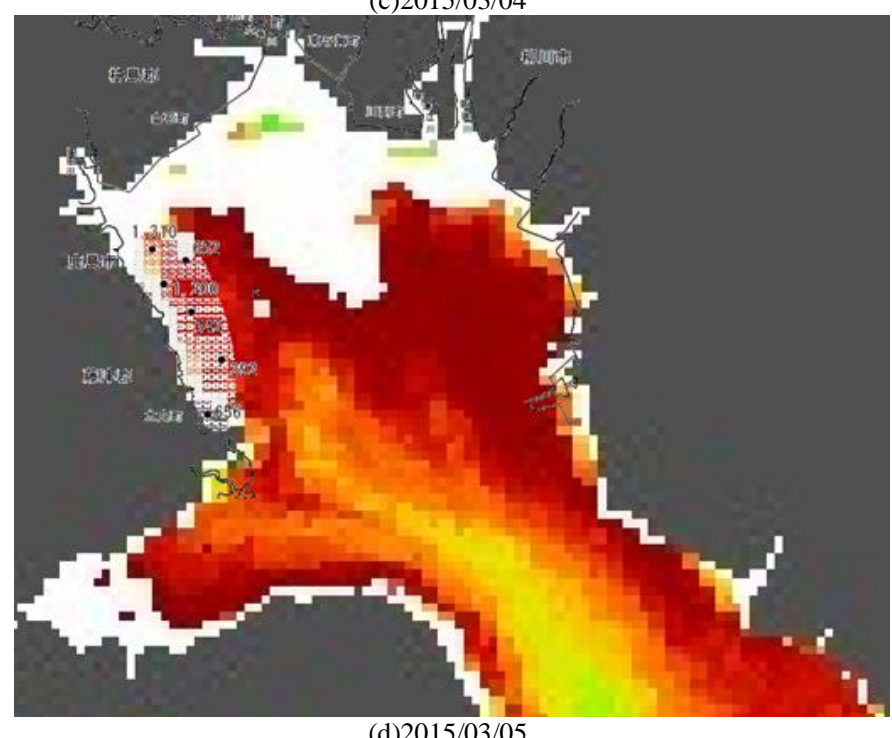

(d) 2015/03/05

Fig. 17. Superimposed images of the truth data and the MODIS data derived chlorophyll-a concentration

\section{CONCLUSION}

Through experiments with the MODIS data derived chlorophyll-a concentration and the truth data of red tide
(Species and the number of cells $/ \mathrm{ml}$ ) which is provided by the Saga Prefectural Fisher Promotion Center, those are acquired for 6 years (winter 2010 to winter 2015), it is found the followings,

1) Asterionella kariana and Skeletonema costatum are used to be appeared in the Ariake Bay area in the winter seasons followed by Eucampia zodiacus appeared in the early spring every year after 2012 in particular, on February 22 2012, February 26 2013, February 62014 and March 62015.

2) It seems that the source of Asterionella kariana and Skeletonema costatum are mostly originated from Shiota river mouth and sometime from Rokkaku river mouth.

3) The red tide propagate from the center of Ariake Bay to Kashima, Tara offshore along with the sea water current in the counter clock wise direction.

4) Through the trend analysis with the superimposed images of the truth data and the MODIS data derived chlorophyll-a concentration which are acquired in the period starting from February 27 to March 5 2015, it is found that chlorophyll-a is distributed densely in the Ariake bay area and Isahaya bay area on February 27. Then the densely distributed chlorophyll-a is flown to the south direction along with the sea water current in the Ariake bay while the densely distributed chlorophyll-a is flown from the Isahaya bay to the Taira-machi and far beyond the Shimabara offshore. Therefore, it may say that the sources of red tide are different between Ariake bay and Isahaya bay.

Further investigations are required to clarify the mechanism of red tide appearance with the consideration three dimensional of cross section analysis the red tide source movement.

\section{ACKNOWLEDGMENT}

The authors would like to thank Dr. Toshiya Katano of Tokyo University of Marine Science and Technology, Dr. Yuichi Hayami, Dr. Kei Kimura, Dr. Kenji Yoshino, Dr. Naoki Fujii and Dr. Takaharu Hamada of Institute of Lowland and Marine Research, Saga University for their great supports through the experiments.

\section{REFERENCES}

[1] Yuji Ito, Toshiya Katano, Naoki Fujii, Masumi Koriyama, Kenji Yoshino, and Yuichi Hayami, Decreases in turbidity during neap tides initiate late winter large diatom blooms in a macrotidal embayment, Journal of Oceanography,69: 467-479. 2013.

[2] Nishikawa T (2002) Effects of temperature, salinity and irradiance on the growth of the diatom Eucampia zodiacus caused bleaching seaweed Porphyra isolated from Harima-Nada, Seto Inland Sea, Japan. Nippon Suisan Gakk 68: 356-361. (in Japanese with English abstract)

[3] Nishikawa $T$ (2007) Occurrence of diatom blooms and damage tocultured Porphyra thalli by bleaching. Aquabiology 172: 405-410. (in Japanese with English abstract)

[4] Nishikawa T, Hori Y (2004) Effects of nitrogen, phosphorus and silicon on the growth of the diatom Eucampia zodiacus caused bleaching of seaweed Porphyra isolated from Harima-Nada, Seto Inland Sea, Japan. Nippon Suisan Gakk 70: 31-38. (in Japanese with English abstract)

[5] Nishikawa T, Hori Y, Nagai S, Miyahara K, Nakamura Y, Harada K, Tanda M, Manabe T, Tada K (2010) Nutrient and phytoplankton dynamics in Harima-Nada, eastern Seto Inland Sea, Japan during a 35year period from 1973 to 2007. Estuaries Coasts 33: 417-427. 
[6] Nishikawa T, Hori Y, Tanida K, Imai I (2007) Population dynamics of the harmful diatom Eucampia zodiacus Ehrenberg causing bleachings of Porphyra thalli in aquaculture in Harima- Nada, the Seto Inland Sea, Japan. Harmful algae 6: 763-773.

[7] Nishikawa T, Miyahara K, Nagai S (2000) Effects of temperature and salinity on the growth of the giant diatom Coscinodiscus wailesii isolated from Harima-Nada, Seto Inland Sea, Japan. Nippon Suisan Gakk 66: 993-998. (in Japanese with English abstract)

[8] Nishikawa T, Tarutani K, Yamamoto T (2009) Nitrate and phosphate uptake kinetics of the harmful diatom Eucampia zodiacus Ehrenberg, a causative organism in the bleaching of aquacultured Porphyra thalii. Harmful algae 8: 513-517.

[9] Nishikawa T, Yamaguchi M (2006) Effect of temperature on lightlimited growth of the harmful diatom Eucampia zodiacus Ehrenberg, a causative organism in the discoloration of Porphyra thalli. Harmful Algae 5: 141147.

[10] Nishikawa T, Yamaguchi M (2008) Effect of temperature on lightlimited growth of the harmful diatom Coscinodiscus wailesii, a causative organism in the bleaching of aquacultured Porphyra thalli. Harmful Algae 7: 561-566.

[11] Syutou T, Matsubara T, Kuno K (2009) Nutrient state and nori aquaculture in Ariake Bay. Aquabiology 181: 168-170. (in Japanese with English abstract)

[12] Harada K, Hori Y, Nishikawa T, Fujiwara T (2009) Relationship between cultured Porphyra and nutrients in Harima-Nada, eastern part of the Seto Inland Sea. Aquabiology 181: 146-149. (in Japanese with English abstract)
[13] Arai K., T. Katano, Trend analysis of relatively large diatoms which appear in the intensive study area of the ARIAKE Sea, Japan, in winter (2011-2015) based on remote sensing satellite data, Internationa Journal of Advanced Research in Artificial Intelligence (IJARAI), 4, 7, 15-20, 2015.

[14] Arai, K., Locality of Chlorophyll-a Concentration in the Intensive Study Area of the Ariake Sea, Japan in Winter Seasons Based on Remote Sensing Satellite Data, Internationa Journal of Advanced Research in Artificial Intelligence (IJARAI), 4, 8, 18-25, 2015.

\section{AUTHORS PROFILE}

Kohei Arai, He received BS, MS and PhD degrees in 1972, 1974 and 1982, respectively. He was with The Institute for Industrial Science and Technology of the University of Tokyo from April 1974 to December 1978 also was with National Space Development Agency of Japan from January, 1979 to March, 1990. During from 1985 to 1987, he was with Canada Centre for Remote Sensing as a Post Doctoral Fellow of National Science and Engineering Research Council of Canada. He moved to Saga University as a Professor in Department of Information Science on April 1990. He was a councilor for the Aeronautics and Space related to the Technology Committee of the Ministry of Science and Technology during from 1998 to 2000. He was a councilor of Saga University for 2002 and 2003. He also was an executive councilor for the Remote Sensing Society of Japan for 2003 to 2005. He is an Adjunct Professor of University of Arizona, USA since 1998. He also is Vice Chairman of the Commission "A" of ICSU/COSPAR since 2008. He wrote 33 books and published 500 journal papers. He is now Editor-in-Chief of IJACSA and IJISA. 